\title{
Going Back to the Basics: Demonstrating Care, Connectedness, and a Pedagogy of Relationship in Education
}

\author{
Anthony Owusu-Ansah ${ }^{1, *} \&$ Lydia Kyei-Blankson ${ }^{2}$ \\ ${ }^{1}$ Middle Grades Education, Albany State University, Albany, Georgia, USA \\ ${ }^{2}$ Educational Administration and Foundations, Illinois State University, Normal, Illinois, USA \\ *Correspondence: Teacher Education Department, Albany State University, 244 Billy C. Black Building, Albany, \\ GA 31705, USA. Tel: 1-229- 430-1265. E-mail: Anthony.Owusu-Ansah@asurams.edu
}

Received: January 19, 2016

Accepted: March 7, 2016 Online Published: March 23, 2016

doi:10.5430/wje.v6n3p1

URL: http://dx.doi.org/10.5430/wje.v6n3p1

\begin{abstract}
Without question, it is imperative in today's era of standards, accountability, and performance assessment, that teachers are skilled in content knowledge and pedagogical strategies. However, the humanistic side of education is equally important for effective teaching and learning. As such, educators need to be reminded of the importance of demonstrating care and connectedness in their classrooms and schools. The current research summary provides literature related to the concepts of care and connectedness and shares strategies for demonstrating care and connectedness in our classrooms and schools. The paper serves as a call to action to all educators, especially those who teach young adolescents, to find a way back to the basic principles of education. Teachers need to exhibit care by adapting their teaching to meet the needs of all students while building connections and positive student-teacher relationships at all levels of education and in all learning environments.
\end{abstract}

Keywords: care; connectedness; pedagogy of relationships; effective teaching \& learning; young adolescents

\section{Introduction}

While academic knowledge and skills are important, students also need to feel respected, understood, appreciated, and cared for to promote growth and learning (Noddings, 2002). Research underscores the power of caring relationships in education and the influence of students' feelings on their ability to learn (Noddings, 1984, 1992, 2005, 2010). Students, who perceive their teachers as caring, have a better sense of belonging in school and tend to show more progress when it comes to learning (Beland, 2014). The current trends in social, economic, and cultural diversity in our classrooms and schools makes it imperative that now, even more than before, educators need to display the humanistic side of teaching in order to effect learning.

The constructs of care and connectedness are crucial at all levels of education, particularly during the middle education grades where our young adolescents are faced with insurmountable challenges in the form of low academic achievement, and the lack of motivation and engagement. In addition, it is at this stage that students start forming attitudes, values and dispositions that will in the long run inform the choices they make in their lives and direct their behavior as adults (National Middle School Association (NMSA), 2010). The act of caring is universal and is essential for building healthy relationships with young adolescents. Teachers must consider a pedagogical shift back to the basic moral virtues of care and connectedness in order to ensure a lasting and positive change in education and in our schools.

\section{The Act of Caring}

Noddings (1984) and Martin (1985) identified caring as the moral virtue necessary for reducing alienation and guiding moral action. The primary purpose of every educator must be to enhance and practice an act of caring because this theme is the "bedrock of education" (Noddings, 2010). Caring for the subject content as well as caring for the student combine to make for effective teaching. As such demonstrating care with students needs to be fundamental in education. Teaching is a caring and humanizing profession and the primary obligation of educators is 
to assist in the realization of students' full humanity (Ayers, 1993). Romano (2000) noted that it is vital for teachers to develop care in schools if we believe care is essential to societal growth and survival. This level of care must start with educators and in our classrooms and schools.

A caring trusting relationship between teacher and student needs to be foundational in any educational environment (Lake, Hass, \& Matthews, 2014). Although the act of caring is considered the "softer side of teaching" (Tate 2006, p. 18), nevertheless, it has been identified as critical for effective teaching and learning at all levels of education (Forrester 2005). Teaching includes both instructional and relational responsibilities. When students believe the adults at their school care about their learning, they feel they are part of their school and are more engaged and more likely to be academically successful (Baker \& Narula, 2012). Noddings (2005) clearly noted in her seminal work on care that unless students are made to believe that they are cared for, educators will continue to see students achieve at only adequate levels. Students need to see their teachers demonstrating care towards them and when they do they in turn learn to reciprocate such feelings towards others. Ojiambo (2015) asserted that the practice of care can address the hidden challenges that impede achievement of educational aims. It is always vital that the education students receive is caring and integrative of essential elements of life (Martin, 1992).

For educators, especially those of young adolescents, demonstrating the act of caring should be one of the ultimate goals of teaching. Through the act of caring, young adolescents will witness a new world of opportunities. In order to increase their chances of feeling cared for and being successful in school, each adolescent within our schools needs to have at least one relationship with a nonfamilial adult who understands their developmental needs and enjoys working with them (Ellerbrock \& Kiefer, 2010; NMSA, 2010, Noddings, 2005). Unfortunately though, much attention has been paid to instruction and managing behavioral issues in our classrooms. It appears the understanding that education includes a humanistic side has taken a backseat to other values (Holcomb, 2010). Schools continue to place less emphasis on the relational aspect of teaching. "A concern for the well-being, love, compassion, and growth of students has been denigrated as unnecessary or weak by some" (Tate 2006, p. 9). It should be noted that a child is not able to learn effectively if they do not feel safe in a caring and nurturing environment (Sims, 2014); an environment that needs to be created in our classrooms and schools.

There is no disputing the fact that teachers need to be knowledgeable in their content area and should be held accountable for instruction. However, it is essential that teachers are encouraged to enact care as well as stay connected with their students. While students and other stakeholders value instructors who are knowledgeable in their area of study, what is more valued is an instructor who takes the time to demonstrate care while providing encouragement, developing a connection, and cultivating a climate of trust and respect (Garza 2009). Teachers who show that they genuinely care and make it a point to develop meaningful relationships with their students irrespective of the environment in which instruction is being delivered, tend to have a positive influence on their students and ultimately on their educational growth (Calabrese, Goodvin, and Niles 2005; Hawk and Lyons 2008).

For our young adolescents in particular, each one of them is "a living work in progress with growth along the road to maturity occurring at different times and rates" (NMSA, 2010, p. 11). These young adolescents expect teachers who are responsive and understand that care, though hard to quantify, still remains a universal characteristic (Noddings, 2005). It is important that educators at all levels, including those who are preparing to become teachers, know that teaching involves more than being an expert in their content area. The ethics of care needs to be taught and developed by all educators. Noddings (1992) supports this and noted the importance of engaging teachers in experiences with other teachers who embrace care in their lives. Teacher candidates in particular, should be encouraged to participate in service learning since service offers many opportunities for reflection, and helps one gain a new sense of self when they recognize that nurturance makes a difference (Swick, 1999). Swick stressed that service learning expands teacher candidates' understanding of what it means to care and can engage them in activities that promote inquiries similar to those they will experience in teaching. With service learning, teacher candidates can transform their thinking about the students they work with while reflecting and being empowered to be more responsive and caring.

Teachers need to understand that caring is an unselfish act and that effective educators continue to demonstrate care even when the care is not reciprocated. Good teaching can be thought of in terms of knowing, loving, and acting for students. The fact that teaching presents hard challenges is not lost especially on those who teach young adolescents but the effective teacher acknowledges this and yet still continues to love and care for students. Tate (2006) pointed out that the kind of love under discussion here refers to the kind of feeling that encompasses the care and concern for the wellbeing of students, in addition to other qualities such as compassion and commitment. Excellent teachers encourage and stimulate their students to dream and learn and help them find ways for those dreams to come true.

In addition to the training needed to effectively teach young adolescents, Noddings (1992) mentioned how dialogue 
and practice are essential in nurturing these pedagogical ideals. When one becomes a teacher, they enter into a caring relationship as the one who cares and the student is in the role of the one being cared for. According to Noddings, the one who cares needs to be engrossed in projects and activities of the one being cared for. Noddings further stressed that this does not:

...Imply romantic love or the sort of pervasive and compulsive "thinking of the other" that characterizes infatuation. It means, rather, that the one caring receives the other, for the interval of caring, completely and nonselectively. She [or he] is present to the other and places her [or his] motive power in his [or her] service...the student is more important than the subject matter (Noddings 1992, p. 178).

The teacher must work together with the student, relate with them, engage them, have dialogue with them, and provide a model for them to follow. Demonstrating an act of caring is important for teachers if they are to fulfill the essential attributes for an education that is equitable, stimulating, developmentally appropriate and empowering (NMSA, 2010). A teacher "cannot nurture the student intellectually without regard for the ethical ideal" (Noddings, 1992, p.179). While some dismiss this ideal to be too hard to attain or involves asking too much of teachers, Noddings insisted that the teacher must be "totally and nonselectively present to each student" (p. 180). It must be pointed out that the wellbeing of the one who is caring is equally as important as the wellbeing of the one being cared for. For the one who is caring to be successful at what they do, the one being cared for needs to reciprocate the feeling to provide motivation for the one caring to continue to care. Therefore, one can offer that for the act of caring to persist, there should be a symbiotic relationship or connectedness between teachers and their students. Education must be designed to encourage and support positive relationships and connectedness between teachers and students.

\section{Teacher-Student Connectedness and School Connectedness}

Educators can achieve a lot with care. But an understanding of the need to connect with the students they teach is equally crucial. In addition, knowledge about school connectedness is important. School connectedness refers to students' perceptions that teachers, administrators and support staff care about them as individuals and about their overall success. The research on school connectedness has emphasized its relationship with academic outcomes and quality of social relationships within a student's experience of school (McNeely, Nonnemaker, \& Blum, 2002). Students who have a stronger sense of connection to school report having greater opportunities for development that can reduce the accumulation of further risks (Anderman \& Freeman, 2004; Catalano \& Hawkins, 1995). Students who experience school connectedness indicate that they like school, feel they belong, believe teachers care about them and their learning, believe that education matters, have friends at school, believe that discipline is fair, and have opportunities to participate in extracurricular activities (Blum, 2005). It is important that students, especially those struggling to know who they are, deserve better connections with the adults they interact with daily in schools.

Thus, school connectedness, like care, contributes greatly to the promotion of educational achievement among students, particularly young adolescents and has been found to be one of the strongest factors that ensures the decrease in the likelihood of exhibiting negative behavior such as substance abuse, violence, and the risk of unintentional injury among both male and female students (Resnick, Bearman and Blum, 1993).

The literature on connectedness has been described from a variety of perspectives; these include critical (Villalpando 2004), feminist (Noddings 19841992 2005), and gender and cultural (Garza 2009; Knight-Diop, 2010), as well as at different levels of educational perspectives. All these views discuss the need for educators to develop meaningful, caring connections and relationships with students. The instructor-student interaction is key to students building critical thinking skills, and maintaining high levels of achievement and development (Rugutt and Chemosit, 2009). Other positive benefits linked with teacher-student interactions include student enjoyment and satisfaction with class and with their non-academic life and improved student attendance and attention (Boice, 1996; Benson, Cohen, and Buskist, 2005).

Immerwahr (2008) explained the concept of pedagogy of relationship using St. Augustine's principles of teachings on love as a lens. St. Augustine's principles focus on the fact that in any ideal educational environment, both the teacher and the learner should function in a reciprocal and dynamic loving relationship in which each is influenced by the other. Immerwahr pointed out that for St. Augustine, the relationship between the teacher and the learner is at the heart of education, and love is the energizing force. Both teacher and learner work together to create this kind of learning environment in order to overcome the lack of engagement, motivation, unresponsiveness, and laziness, and disrespectfulness in the classroom. Again, teachers and learners coexist in a relationship characterized by constructivist theories and principles. 
What makes the teacher-learner relationship work and teaching and learning effective is reciprocal love, concern, and care. Also, during their time together in the relationship, the teacher is supported to open up to the student instead of portraying an impersonal persona. These principles are supported by Ginsberg (2007) who noted that the most effective teachers are those whose students perceive as "revealing" or who are willing to disclose important pieces of their work, experiences, and personal lives. That does not say that a teacher needs to be less cautious about working with their students. Rather, they must be willing to share part of themselves with their students in order to help them succeed.

\section{Relating Care and Connectedness with Student Backgrounds}

Students from different backgrounds view caring in different ways. Garrett, Barr, and Forsbach-Rothman (2009) found that students of different ethnicities valued different caring characteristics. For example, students of Caucasian descent placed more value on friendship and personal values while students of color valued developing relationships and activities. Specifically, Latino and African-American students valued more the provision of academic support. Also, African American students perceived verbal encouragement, assistance, and setting high expectations as caring teacher traits. Garza, Ovando, \& Semour (2010) also found that students' gender had an effect on how they perceived teacher caring. Their study showed that male students reported lower levels of caring compared to females. Although Baker \& Bridger (1997) indicated an ethic of caring is equally important to men and women, Gilligan (1982) found evidence that care was more likely to be found among women than among men.

The key questions teachers need to ask is how they can help improve their students' lives in their classrooms and schools. This is of particular importance for teachers of young adolescents. The focus should be on what matters to these students and how they fit into their classrooms, what to accomplish with the students or how programs affect student growth, development and achievement (NMSA, 2010). Above all, these decisions need to be taken with the student backgrounds in mind. What is important is to ask about their needs- developmental, emotional, physical, psychological and psychosocial - how they are cared for or left to care for themselves and the possibilities for connectedness with those they interact with. These offer the best potential to unlocking answers to the broader issues of program improvement and achievement that affect students, particularly young adolescents.

\section{Demonstrating Care, Connectedness, and a Pedagogy of Relationship}

The research shows that instructors who care, show concern for their students, and interact with them, tend to be able to motivate them more. These outcomes can be realized in any learning environment, and especially in environments with young adolescents. Care and connectedness may be broad terminologies that encompass many meanings regarding how teachers and students need to view, treat, and relate to each other but they are essential to assisting students, especially young adolescents and promoting effective teaching and learning. The two concepts allow the teacher to be mindful and appropriately attentive to the needs of their students. A teacher's care is demonstrated in how they view and relate with their students. O'Connor (2008) defined caring as showing "emotions, actions, and reflections that result from a teacher's desire to motivate, help or inspire their students" (p. 117). Caring is critical to guiding instruction, student discipline, school policy formation, as well as other important details for daily operations (Collier, 2005). Enacting care and connectedness come with intentionality. Teachers need to plan and think of how to portray caring and connectedness to their students (Noddings, 1992). Teachers should use effective classroom management and teaching methods to foster a positive learning environment (CDC, 2010).

A devil-advocate's question may be: Is it possible that students can learn without the benefit of a caring teacher or without the teacher exhibiting concern, or without the teacher connecting with the student? Noblit, Rogers, and McCadden (1995) warned that the opportunities for learning in such an environment do exist. In such situations, teaching and learning, however, may be significantly restricted. Therefore, in addition to being well-versed in the content to be taught, the teacher must dedicate time, energy and resources in nurturing caring relationships with their students. Noddings (1992) believes that taking time to build trusting relationships guided by the ethics of care, concern, and connection allows teachers to support students' moral development, which is most important for society.

Effective teachers demonstrate pedagogical care, concern and connectedness by tailoring their teaching and learning activities to the diverse needs of students. Students who are cared for and who are connected with their teachers are exposed to diverse educational settings, adaptive pedagogy and culturally responsive curricula. These students also learn to accept cultural differences. Teachers show care, concern, and connectedness by being accountable for their students' learning outcomes and make it a point to show and enact respect in the classroom environment. Providing feedback and offering instructional accommodation and choices are other ways that teachers can exhibit care, concern, 
and connectedness for their students. Establishing interpersonal relationships involves teachers showing personal interest in their students as well as maintaining a fair teaching and learning environment.

In general, a teacher shows care by not being judgmental but rather respectful, patient, available, dependable, flexible, supportive, open, warm and genuine, and by being receptive of students from all backgrounds. Caring teachers with clear understanding of the positives of school connectedness provide positive support to students and show a genuine interest in the lives of students and their families. They express the desire to see students succeed, make students feel welcome by learning and remembering their names, and communicate availability. In short, they show an interest in the students' academic and non-academic affairs. Caring and connectedness can also be observed through a teacher's voice, actions, body language, facial expressions; in essence, in both what is spoken and unspoken. The outcome of teacher care and connection is increased student self- image and sense of self-worth (Collier 2005).

Traits displayed by caring teachers can be classified as either nonverbal or verbal immediacy. Immediacy refers to overt forms of communication that enhance the closeness between students and teachers. The research on teacher immediacy provides the firmest foundation for the idea that caring makes a difference in students' educational experiences, retention of course content, and student achievement. Danielsen, Wiium, Wilhelmsen, and Wold (2010) found in their research that students of caring teachers attained higher levels of achievement and school wellbeing.

Educators need to embrace Noddings' $(1984,1992)$ framework of care by cultivating and displaying care, demonstrating connectedness and by building relationships. Teachers and administrators need to share in this responsibility with the goal to helping students, particularly young adolescents navigate their world of transitions and ultimately becoming responsible adults and good citizens. Teachers should not forget that when students are cared for, they learn to respond in similar fashion to the needs of others.

According to Garza (2009), teaching and modeling the ethics of care lead to more positive schooling experiences for students. Although some think caring for students shows a sign of weakness on the part of the instructor, caring is an important dimension of effective teaching that needs to be prioritized by all instructors. Garza encourages teachers to "examine student voices more carefully and in so doing caring for students may look different from what common practices dictates" (p. 297). Caring should be a purposeful act and must depend on the needs of the individual student. "When teachers operate from the ethic of care and connectedness they consciously make a moral commitment to care for and to teach students and develop reciprocal relationships with them" (Pang 2005, p. 218).

Caring and school connectedness always involve developing a pedagogy of relationship. These are critical for minimizing unwanted statistics such as student dropout rates especially among at-risk students and those who are more likely to have behavioral problems. In his research on the topic of caring, Boice (1996) found that when instructors are uncaring their students are also uncaring and connectedness is impacted. Teachers' apathy or hostility in the classroom and beyond often leads to increased student misbehavior and disruptiveness and decreased constructive class engagement.

According to Johnson and Thomas (2009), teachers, particularly those who teach young adolescents might consider the following in order to create a caring classroom. A teacher can create a caring environment by simply asking a student what they did over the weekend or if the soccer game they had the night before went well. Another way a teacher can show that he or she cares is to go beyond traditional classroom teaching to take students on field trips in order to show them how what they are learning in the classroom relates to real life.

A caring teacher who considers connectedness vital for student achievement will get to know the families of his/her students and will make themselves available for family questions, concerns, or needs that affect the student's life. The same teacher might consider applying fair and consistent disciplinary policies that are collectively agreed upon and fairly enforced. Teachers must ensure that every student feels close to at least one supportive adult at school (Croninger \& Lee, 2001; National Research Council, 2004). Also, teachers can show their students that they care by providing extra support and time to students who are struggling in their classrooms. Teachers should know that students notice and appreciate it when a teacher does their possible best to help them out (Frego, 2006).

According to Meyer (2009), caring or developing a rapport with students affects attitudes toward the class, students' academic behavior, and the extent of their learning; Expressing care, communicating respect, behaving sensitively, and remaining kind and engaged with students affects the broader learning community. Enacting care and connectedness are effective characteristics that continually help promote academic achievement, positive attitudes, motivation, and learning. Teachers need to show a genuine interest in their students as they do with their subject matter. They need to be open, available, and responsive to students. They need to show respect and concern for their students, see them as 
individuals and not just learners, and welcome interaction with them. Strategies for improving teacher care and connectedness as suggested by authors such as Hawk and Lyons (2008) and Meyer (2009) include the following:

1. Get to know the students as individuals through the administration of a survey as a "first day of class" activity. It is important that students' goals and expectations be assessed. Teachers need to know their students and let their students get to know them.

2. Recognize that students are individuals who have diverse learning styles and backgrounds. As much as possible, a variety of teaching approaches, activities, and assignments need to be applied.

3. Invite student input in class and of the need to be aware and responsive to the classroom climate.

4. Provide timely, specific, and constructive feedback on activities, assessments, and assignments. Students need to know as early as possible how they are progressing in class and what they need to change in order to be successful in class.

5. Provide a safe, supportive, and fair learning environment where students are encouraged to share their ideas and ask questions. Students need to be able to express themselves in the form of questions or need to respond to questions without the fear of being wrong. Cloninger (2008) challenged instructors to put themselves in the mind and experiences of their students as a demonstration of care.

6. Demonstrate clarity when it comes to classroom behavioral and performance expectations. Students need to be clear on the class expectations. Each learning objective and activity must come with a rationale. There is a need to provide students with directions and examples for assignments using rubrics and samples of past and exemplary work. Also, there is the need to align the activities, assessments, and assignments with the class outcomes, and to demonstrate how class activities will help build the necessary and required career skills later in life.

Teachers need to be empathetic, teach while modeling caring, showing concern, and developing positive connections with students. Teachers should allow their students to know them. They need to be able to reveal aspects about themselves that allow students to see them as real people. Cloninger (2008) suggested that, "love creates a socio-cognitive context in which knowledge is imbued with different shades of understanding" (p. 208). Caring relationships and meaningful academic experiences promote a sense of community associated with academic and personal benefits. Caring teachers will continue to hold the key to student success.

Regarding school wide programs, Baker and Bridger (1997) suggested educational strategies such as cooperative learning, including components that promote community and prosocial development, and encourage student sense of community and connection. There should be programs and approaches that create positive and purposeful peer support and peer norms (Wingspread Declaration of School Connections, 2004). Contemporary scholars claim that "the self does not exist apart from relationships, that one is interconnected with others in essential ways, and that the moral ideal includes responsibility towards others, connection, and compassion" (Brabeck, 1989, p. xi). The importance of caring connections is evident in many theories of moral development and child development (Baker and Bridger, 1997).

Pedagogically relational schools structure themselves and their pedagogical practices so that children foster personal relationships with teachers and peers and develop a meaningful commitment to work. Students perform to their potential with a sense of belonging. Teachers in caring schools adopt different roles and functions. They purposively nurture caring relationships with students, express greater warmth and supportiveness toward students and share and spend more time listening to and talking with students about personal and social issues (Solomon, Watson, Battitstich, Schaps, and Delucchi 1992).

According to Baker and Bridger (1997), teachers in such systems maintain their central authoritative role in the classroom, providing structure, direction, monitoring, and feedback to students. They use students' comments as springboards for discussion, use problem-solving approaches and elicit more critical thinking and discussion. They purposively mentor students in other areas than academics. They address social ethical and civic behavior as part of their curriculum and use that during the day to address interpersonal and classroom behavior. They encourage cooperation instead of competition in the class and group work instead of individual projects. They also provide students with a choice of what and how to learn.

Emphasizing relational approaches by attending to the social context in which learning occurs is important for improving schooling. Relationally oriented approaches foster the development of caring relationships among students and teachers at schools as a means of affecting children's intellectual, social, and emotional growth (Baker and Bridger 
1997). The ethics of care and connectedness form the basis of school or classroom-wide community of interdependent learners. A community orientation based on caring and support allows children to appraise school as a meaningful social context in which to function. The ensuing sense of belonging and psychological safety, combined with significant academic work that promotes engagement in the community, enables children to achieve to their potential. A positive teacher/student relationship creates the class atmosphere necessary to maximize a student's mental state of readiness. The quality of the relationship is the keystone for all aspects of class management. Schools organized around ethics of care and connectedness transmit these ideals to students in the following basic ways: they engage them in informal and formal instruction in ethics and core values such as caring, respect, and responsibility; they encourage them to practice the ethic of care in service to others and, they confirm a commitment to it at all levels of the school environment and their personal lives.

\section{References}

Ayers, W. (1993). To teach: The journey of a teacher. New York: Teachers College Press

Baker, J. A., \& Bridger, R. (1997). Schools as caring communities: A relational approach to school reform. School Psychology Review, 26(4), 586.

Baker, K., \& Narula, B. (2012). The connected adolescent: Transitioning to middle school. Retrieved from http://files.eric.ed.gov/fulltext/EJ971418.pdf

Beland, K. (2014). Easing the transition to middle adolescence. Journal of Research in Character Education, 10(1), 61-67.

Benson, T. A., Cohen, A. L., \& Buskist, W. (2005). Rapport: Its relation to student attitudes and behaviors toward teachers and classes. Teaching of Psychology, 32, 236-238.

Blum, R. (2005). School connectedness: Improving students' lives. Johns Hopkins Bloomberg School of Public Health: Baltimore, MD.

Boice, B. (1996). Classroom incivilities. Research in Higher Education, 37, 453-486. http://dx.doi.org/10.1007/BF01730110

Brabeck, M. M. (1989). Who cares? In M. M. Brabeck (Ed.), Who cares: Theory, research, and educational implications of the ethic of care (pp. xi-xviii). New York: Praeger Publishers.

Calabrese, R. L., Goodvin, S., \& Niles, R. (2005). Identifying the attitudes and traits of teachers with an at-risk student population in a multi-cultural urban high school. International Journal of Educational Management, 19(5), 437-449. http://dx.doi.org/10.1108/09513540510607761

Cloninger, K. (2008). Giving beyond care: An exploration of love in the classroom. Curriculum \& Teaching Dialogue, 10(1), 193-211.

Collier, M. D. (2005). An ethic of caring: The fuel for high teacher efficacy. Urban Review, 37(4), 351-359. http://dx.doi.org/10.1007/s11256-005-0012-4.

Croninger, R. G., \& Lee, V. E. (2001). Social capital and dropping out of high school: Benefits to at-risk students of teachers' support and guidance. Teachers College Record, 103(4), 548-581.

Danielsen, A. G., Wiium, N., Wilhelmsen, B. U., \& Wold, B. (2010). Perceived support provided by teachers and classmates and students' self-reported academic initiative. Journal of School Psychology, 48(3), 247-267. http://dx.doi.org/10.1016/j.jsp.2010.02.002

Ellerbrock, C., \& Kiefer, S. (2010). Creating a ninth-grade community of care. The Journal of Educational Research, 103, 393-406. http://dx.doi.org/10.1080/00220670903383085

Forrester, G. (2005). All in a day's work: Primary teachers 'performing' and 'caring'. Gender \& Education, 17(3), 271-287. http://dx.doi.org/10.1080/09540250500145114.

Frego, K. A. (2006). Authenticity and relationships with students. New Directions for Adult \& Continuing Education, 111, 41-50. http://dx.doi.org/10.1002/ace.226

Garrett, T., Barr, J., \& Rothman, T. (2009). Perspectives on caring in the classroom: Do they vary according to ethnicity or grade level? Adolescence, 44(175), 505.

Garza, R. (2009). Latino and white high school students' perceptions of caring behaviors: Are we culturally responsive to our students? Urban Education, 44(3), 297-321. http://dx.doi.org/10.1177/0042085908318714 
Garza, R., Ovando, M. N., \& Seymour, C. E. (2010). Latino and White students' perceptions of teacher behaviors that convey caring: Do gender and ethnicity matter? Current Issues in Education, 13(1), 1-30.

Gilligan, C. (1982). In a different voice: Psychological theory and women's development. Cambridge, MA: Harvard University Press.

Ginsberg, S. (2007). Faculty self-disclosure in the college classroom. The Teaching Professor, 21(4), 5.

Hawk, T. F., \& Lyons, P. R. (2008). Please don't give up on me: When faculty fail to care. Journal of Management Education, 32(3), 316-338. http://dx.doi.org/10.1177/1052562908314194

Holcomb, S. (2010). Going beyond care, concern, and connection to create a classroom environment of compassionate connectivity. The University of Oklahoma, Oklahoma. Dissertations \& Theses: Full Text. (Publication No. AAT 3263442).

Immerwahr, J. (2008). Augustine's advice for college teachers: Ever ancient, ever new. Metaphilosophy, 39(4), 656-665. http://dx.doi.org/10.1111/j.14679973.2008.00568.x

Lake, P. K., Hass, B. K., \& Matthews, M. (2014). Fit to care: An action research study exploring the use of Communication Theory to strengthen caring relationships between teachers and students. International Journal for Human Caring, 18(3), 15-25. http://dx.doi.org/10.20467/1091-5710-18.3.15

Martin, J. R. (1985). Reclaiming a conversation. New Haven: Yale University Press.

Martin, J. R. (1992). The school home: Rethinking schools for changing families. Cambridge, MA: Harvard University Press.

McNeely, C., Nonnemaker, J., Blum, R. (2002). Promoting School Connectedness: Evidence from the National Longitudinal Study of Adolescent Health. Journal of School Health, 72, 138-146. http://dx.doi.org/10.1111/j.1746-1561.2002.tb06533.x

National Middle School Association [NSMA]. (2010). This we believe: Keys to educating young adolescents. Westerville, Ohio: Association for Middle Level Education.

National Middle School Association. (2010). This we believe: Keys to educating young adolescents. Westerville, Ohio: Association for Middle Level Education.

National Research Council (2004). Engaging schools: Fostering high schools students' motivation to learn. Washington D. C: The National Academies Press.

Noblit, G., Rogers, M. \& McCadden, K. (1995). In the meantime: The possibilities of caring. Phi, Delta, Kappan, 76(9), 680-685.

Noddings, N. (1984). Caring: A feminine approach to ethics and moral education. Berkeley: University of California Press.

Noddings, N. (1992). The challenge of care in schools: Care in schools. New York: Teachers College.

Noddings, N. (2002). Educating moral people: A caring alternative to character education. New York: Teachers College Press.

Noddings, N. (2005). An alternative approach to education ( $2^{\text {nd }}$ ed.). New York: Teachers College Press.

Noddings, N. (2005). The challenge to care in schools: An alternative approach to education. New York: Columbia University Press.

Noddings, N. (2010). The maternal factor: Two paths. Berkley: University of California Press.

O'Connor, K. E. (2008). 'You choose to care': Teachers, emotions and professional identity. Teaching and Teacher Education, 24(1), 117-126. http://dx.doi.org/10.1016/j.tate.2006.11.008

Ojiambo, P. O. (2015). Care theory comes alive in an African school: Starehe boys' center and school. The International Journal of Pedagogy and Curriculum, 21, 13-27.

Pang, V. O. (2005). Multicultural education: A caring-centered reflective approach. New York. McGraw-Hill.

Romano, R. (2000). Forging an educative community: The wisdom of love, the power of understanding and the terror of it all. New York: Peter Lang.

Rugutt, J., \& Chemosit, C. (2009). What motivates students to learn? Contribution of student-to-student relations, student-faculty interaction, and critical thinking skills. Educational Research Quarterly, 32(3), 16-28. 
Sims, M. (2014). Is the care-education dichotomy behind us? Should it be? Australasian Journal of Early Childhood, 39(4), 3-11.

Solomon, D., Watson, M., Battistich, V., Schaps, E., \& Delucchi, K. (1992). Creating a caring community: Educational practices that promote children's prosocial development. In F. K. Oser, A. Dick, \& J. Patry (Eds.), Effective and responsible teaching: The new synthesis. San Francisco, CA: Jossey-Bass.

Swick, K. J. (1999). Service learning helps future teachers strengthen caring perspectives. Clearing House, 73(1), 29. http://dx.doi.org/10.1080/00098659909599635

Tate, P. M. (2006). Academic and relational responsibilities of teaching. Journal of Education, 187(3), 1.

Villalpando, O. (2004). Practical considerations of critical race theory and Latino critical theory for Latino college students. New Directions for Student Services, 105, 31-50. http://dx.doi.org/10.1002/ss.115

Wingspread Conference (2004, September 1). Declaration on School Connections. Journal of School Health, 74(7), 233-234. 